\title{
PHYSICAL ACTIVITY, HEALTH CONDITION AND LIFESTYLE OF ACADEMIC YOUTH
}

\author{
BARBARA GRABOWSKA \\ Division of Health Promotion, Department of Public Health \\ Faculty of Health Sciences, Wrocław Medical University \\ Bartla 5, 51-618 Wrocław, Poland \\ e-mail address: barbara.grabowska@umed.wroc.pl \\ ORCID: https://orcid.org/0000-0001-7466-1280
}

\section{MARIOLA SEN}

Division of Health Promotion, Department of Public Health

Faculty of Health Sciences, Wrocław Medical University

Bartla 5, 51-618 Wrocław, Poland

e-mail address: mariola.sen@umed.wroc.pl

ORCID: https://orcid.org/0000-0002-6790-654X

\author{
LUBA JAKUBOWSKA \\ Division of Health Promotion, Department of Public Health \\ Faculty of Health Sciences, Wrocław Medical University \\ Bartla 5, 51-618 Wrocław, Poland \\ e-mail address: luba.jakubowska@umed.wroc.pl \\ ORCID: https://orcid.org/0000-0002-0507-6595
}

Thesis. Living in the age of modern inventions one forgets about one of the best medications for many health problems, which is physical activity. The role and task of physical activity at an early age, as well as at any other stage of life, is very important in the prevention of civilization diseases, which is why it is crucial to monitor it.

Aim. The aim of the study was to assess the relationship between the level of physical activity, state of health and the lifestyle of academic youth.

Methods. The research was carried out among students from three universities in Wrocław ( $n=629)$ : University of Wrocław (UWr), Wrocław University of Science and Technology (PWr) and Wrocław Medical University (UM). The study used self-constructed questionnaires: physical activity questionnaire, health questionnaire, and a lifestyle questionnaire. The following statistical analyses of the results were used: Shapiro-Wilk test, Pearson chi-square test independence, post-hoc test, analysis of variance (ANOVA), correlation coefficient rank (Spearman) and Pearson's correlation coefficient. In the calculations, the package of computer programs STATISTICA v. 9.0 was used. Hypotheses verified at the level of $\mathrm{p} \leq 0.05$. 
Results. Health was the highest-rated of the studied factors. In addition, it was found that as many as $67.7 \%$ of students from all universities represent a very good level of lifestyle. $68.4 \%$ of the respondents were characterised by a very good health potential. Research has shown that the physical activity of students from the Medical University is at a higher level than students of PWr and UWr. Among the demographic variables, gender turned out to be important (men perform physical activity more often than women, while BMI and place of origin did not affect the physical activity of students).

Key words: physical activity, lifestyle, health status, body mass index (BMI), academic youth

\section{INTRODUCTION}

T iving in the age of modern inventions, the rapid pace of technology development and lifestyle resulting from, inter alia, the above conditions, one of the best medicines for many health problems is forgotten, which next to diet is the basis for the proper functioning of the biological body: physical activity.

In the public opinion survey conducted in 2018 by the Ministry of Sport and Tourism 1067 Poles took part. Less than a fifth of them answered that they practice sport regularly and that physical activity is a very important aspect in their lives. More than a half $(55.1 \%)$ of respondents do sports only from time to time, while a quarter (25.6\%) do not like this type of activity. The other participants of the study sporadically engage in a sport discipline using justifications in the form of the lack of time, health or long distance to the sports centres from the place of residence (Ministry of Sport and Tourism, 2018).

Meanwhile, the human body in its nature is predisposed to exercise (Biernat, 2011). A young person needs regular physical activity in his life to develop, function and, above all, keep his/ her health in the best condition until late age.

International examinations assessing the level of physical activity of residents of 15 European Union countries and 6 countries participating in the CINDI WHO programme conducted in the late 1990s show that the percentage of sedentary working people ranged from 40 to 80\% (Drygas, Skiba, Bielecki, et al., 2001; Varo, Martinez-Gonzales, de Irala-Estevez, et al. 2003).

The above data indicates that at the present time in Poland and Europe, a sedentary lifestyle is widespread. Young people also observe similar tendencies and habits. Most of their time, young people spend in front of a computer, TV, playing computer games while sitting in a restaurant. That is why in recent years the interest in proper preparation of the young generation to care for their own health has increased significantly and active schemes for public health have been taken.

Another factor reducing physical activity may be the urbanisation of society. Urban lifestyle is usually associated with low physical activity, and sometimes with high mental stress, contributing to the growing burden of disease (Chen, de Vries, Assmuth, Dick, Hermans, Hertel, \& Reis, 2019). 
It should be noted that global lists of risk factors for civilisation diseases (Pomerlau, Pereson, Ostbye, Speechley, \& Speechle, 1997) indicate a lack of physical activity as a very important factor in the development of chronic diseases.

The high incidence of overweight and obesity in addition to low physical activity among populations from all over the world contributes greatly to the increased incidence of civilisation diseases.

Undertaking physical activity by young people depends on many factors, among which one of the more important is the perforated lifestyle which has become the subject of our research. In addition, the relationship between physical activity and state of health was checked.

Systematic physical activity is important at every stage of human life. In the case of children it does not only ensure proper physical but also mental development. For adolescents it serves as one of the aspects preventing the onset of chronic diseases. When it comes to elderly people the systematic physical activity is crucial for maintaining independence and good quality of life (Bąk-Romaniszyn, 2013).

\section{MATERIAL AND METHODS}

The study covered students from three universities in Wrocław ( $\mathrm{n}=629)$ : 206 students from the University of Wrocław, comprising 99 women (48.1\%) and 107 men (51.9\%); 217 students from the Wrocław University of Science and Technology, comprising 109 women (50.2\%) and 108 men (49.8\%), 206 students from the Wrocław Medical University, comprising 104 women (50.5\%) and 102 men (49.5\%) ). 474 respondents (75.4\%) lived in the city, 155 students $(24.6 \%)$ lived in the countryside (Table 1$)$.

Table 1.

Characteristics of the tested group

\begin{tabular}{lcccc}
\hline & \multicolumn{3}{c}{ University } & \multirow{2}{*}{ All together } \\
\cline { 2 - 4 } & $\begin{array}{c}\text { Mrocław } \\
\text { University }\end{array}$ & $\begin{array}{c}\text { University } \\
\text { of Wrocław }\end{array}$ & $\begin{array}{c}\text { Wrocław } \\
\text { University } \\
\text { of Science }\end{array}$ & \\
Number of students & $206(100 \%)$ & $206(100 \%)$ & $217(100 \%)$ & $629(100 \%)$ \\
and Technology & & \\
Women & $104(50.5 \%)$ & $99(48.1 \%)$ & $109(50.2 \%)$ & $312(49.6 \%)$ \\
Men & $102(49.5 \%)$ & $107(51.9 \%)$ & $108(49.8 \%)$ & $317(50.4 \%)$ \\
Countryside & $53(25.7 \%)$ & $46(22.3 \%)$ & $56(25.8 \%)$ & $155(24.6 \%)$ \\
City & $153(74.3 \%)$ & $160(77.7 \%)$ & $161(74.2 \%)$ & $474(75.4 \%)$ \\
\hline
\end{tabular}

Source: own research.

The following questionnaires were used:

Physical activity questionnaire included questions about the type, time and frequency of physical activity. The health questionnaire contained closed questions 
regarding anthropometric features: height and weight, general health, morbidity for individual disease entities (diseases of the heart, circulatory system, blood vessels, urinary system, lungs, digestive system, liver, thyroid, nervous system, bone-joint system, blood and coagulation system, eyes, vision defects, infectious diseases, metabolic disorders, mood changes, rheumatism) and information on the incidence of disability. The lifestyle questionnaire contained questions related to the consumption of: alcohol, smoking and drug use. The questions also contained information about: the amount of liquids drunk during the day, regular consumption of food such as fruits, vegetables, meat, dairy products, cereal products and eating fast food.

In order to check the reliability of the questionnaires used, the questionnaires were validated. The analysis of the internal consistency of the scale indicates good cohesion determined by the correlation of the questions creating the scale with the total result. The results of reliability for individual questions of the questionnaires were within the range of $0.680-0.750$ alpha Cronbach, which indicates good psychometric quality of the scale. Cronbach's alpha coefficient $=0.740$.

Due to the complexity of individual aspects examined, and examination of the correlation between them and in order to make a current assessment of each student while instantaneously taking into account many features, a synthetic comprehensive measure (STM) was created (Waszkiewicz, 2017 in: Grabowska, 2017) with construction features based on three synthetic partial measures (SPMs) assessing each of the aspects examined, namely: SPM "health status", SPM "lifestyle", SPM "physical activity currently".

For each student, the values of all synthetic partial measures were calculated: "health status", "lifestyle", "physical activity currently" and the magnitudes of a synthetic comprehensive measure describing the health potential of students. Information for the construction of indicators comes from the questionnaire completed by the students, according to the questionnaire of their own authorship.

The construction of each of the synthetic partial measures: "health status", "lifestyle", "physical activity currently" is described by the formula: $S P M " u^{\prime \prime}{ }_{k}=\frac{1}{c} \sum_{i=1}^{j} O_{u i}$. The calculated partial meter is in the range 0-1, where " 0 " means undesirable values (worst) and " 1 " means desirable values (best).

For each student $(\mathrm{k})$ the sum of synthetic partial values of partial meters $\left(\sum_{u=1}^{z} S P M " u^{\prime \prime}\right)$. In order to obtain the value of the synthetic total meter (STM) ranging from 0.0 to 1.00, the obtained value was divided ( $\sum_{u=1}^{z} S P M$ " $u$ ") by the number of synthetic partial measures $(\mathrm{z}=3)$. Formula: $S T M_{k}=\frac{1}{z} \sum_{u=1}^{z} S P M " u$ ".

The statistical analysis of the results was based on the Shapiro-Wilk test, Pearson's chi-square independence test, post-hoc test, analysis of variance (ANOVA), rank correlation coefficient (Spearman) and Pearson's correlation coefficient. In the calculations, the package of computer programs STATISTICA v. 9.0 was used. The approval of the bioethics commission No. KB 127/2011 was obtained. 
The statistical analysis of the results was based on the Shapiro-Wilk test, Pearson's chi-square independence test, post-hoc test, analysis of variance (ANOVA), rank correlation coefficient (Spearman) and Pearson's correlation coefficient. In the calculations, the package of computer programs STATISTICA v. 9.0 was used. The approval of the bioethics commission No. KB $127 / 2011$ was obtained.

\section{RESULTS}

\section{Health status}

From all examined aspects health is the highest rated one by students of Wrocław universities. At all universities, the SPM values received "health" were very high. Most people are characterised by very good health (tab. 2). There was no relationship between the state of health and the type of university $(p=0.358, p>$ $0.05)$; gender $(p=0.313 ; p>0.05)$ and place of residence. $(p=0.567 ; p>0.05)$.

\section{Table 2.}

Basic statistics (numbers and proportions) of SPM level "health status".

\begin{tabular}{|c|c|c|c|c|c|}
\hline $\begin{array}{l}\text { Level of the } \\
\text { meter: }\end{array}$ & $\begin{array}{c}\text { Altogether } \\
N=629\end{array}$ & $\begin{array}{c}\text { UWr } \\
N=206\end{array}$ & $\begin{array}{c}\text { PWr } \\
N=217\end{array}$ & $\begin{array}{c}\text { UM } \\
N=206\end{array}$ & $\begin{array}{c}\text { Chi-square } \\
\text { test } \\
p\end{array}$ \\
\hline „health status": & & & & & 0.358 \\
\hline Good & $1 \quad(0.2 \%)$ & $(0.0)$ & $(0.0)$ & $(0.5)$ & \\
\hline Very good & $628(99.8 \%)$ & $\begin{array}{c}206 \\
(100.0 \%)\end{array}$ & $\begin{array}{c}217 \\
(100.0 \%)\end{array}$ & $206(99.5 \%)$ & \\
\hline
\end{tabular}

Source: own research.

Among all the students, divided by the type of university, more than $2 / 3$ $(68.4 \%)$ of the respondents had normal body mass (including $74.8 \%$ of the university, PWR 69.1\%, UM 61.2\%). Overweight and obesity was most often observed among UM students (28.2\%). $10.7 \%$ of young people have underweight (Table 3).

Table 3.

Body mass index - BMI at each university

\begin{tabular}{|c|c|c|c|c|}
\hline \multirow[b]{2}{*}{ BMI } & \multicolumn{3}{|c|}{ University } & \multirow{2}{*}{$\begin{array}{l}\text { Alltogether } \\
n=629\end{array}$} \\
\hline & $\begin{array}{c}\mathbf{U W r} \\
n=206\end{array}$ & $\begin{array}{c}\text { PWr } \\
n=217\end{array}$ & $\begin{array}{c}\mathbf{U M} \\
n=206\end{array}$ & \\
\hline underweight & $19(9.2 \%)$ & $26(12.0 \%)$ & $22(10.7 \%)$ & $67(10.7 \%)$ \\
\hline correct value & $154(74.8 \%)$ & $150(69.1 \%)$ & $126(61.2 \%)$ & $430(68.4 \%)$ \\
\hline overweight & 27 (13.1\%) & $29(13.4 \%)$ & $55(26.7 \%)$ & $111(17.6 \%)$ \\
\hline obesity & $6 \quad(2.9 \%)$ & $12(5.5 \%)$ & $3(1.5 \%)$ & $21 \quad(3.3 \%)$ \\
\hline
\end{tabular}

Pearson's chi-square test: ${ }^{2}=23.2 ; d f=6 ; p=0.001$

Source: own research. 
Proper body weight was more frequently observed in the case of women $(73.1 \%)$ than men $(63.7 \%)$. Among men, nearly every third person was overweight or obese $(27.8 \%$ vs. $7.4 \%)$, and underweight accounted for $2.8 \%$ of the subjects. In the case of women, overweight and obesity occurred more often than every 10 th of the examined $(7.4 \%$ vs. $1.0 \%)$, whereas underweight was reported in $18.6 \%$ of women. (Table 4 ).

Table 4.

The number of students differing in body mass index (BMI) and type of university

\begin{tabular}{|c|c|c|c|}
\hline \multirow[b]{2}{*}{ BMI } & \multicolumn{2}{|c|}{ Sex } & \multirow{2}{*}{$\begin{array}{c}\text { Alltogether } \\
n=629\end{array}$} \\
\hline & $\begin{array}{c}\text { Women }(\mathbf{W}) \\
n=312\end{array}$ & $\begin{array}{c}\text { Men (M) } \\
n=317\end{array}$ & \\
\hline underweight & $58(18.6 \%)$ & $9 \quad(2.8 \%)$ & $67(10.7 \%)$ \\
\hline correct value & $228(73.1 \%)$ & $202(63.7 \%)$ & $430(68.4 \%)$ \\
\hline overweight & $23(7.4 \%)$ & $88(27.8 \%)$ & $111(17.6 \%)$ \\
\hline obesity & $3(1.0 \%)$ & $18 \quad(5.7 \%)$ & $21 \quad(3.3 \%)$ \\
\hline
\end{tabular}

Pearson's chi-square test: ${ }^{2}=86.2 ; d f=3 ; p=0.001$

Source: own research.

The percentage of overweight male students is more than three times higher than among female students $(p=0.001)$. (Table 4).

\section{Lifestyle}

Table 5.

Basic statistics (numbers and proportions) SPM "lifestyle" due to gender

\begin{tabular}{lcccc}
\hline $\begin{array}{l}\text { Level of the } \\
\text { meter: }\end{array}$ & $\begin{array}{l}\text { Overall } \\
N=629\end{array}$ & $\begin{array}{c}\text { Women } \\
N=312\end{array}$ & $\begin{array}{c}\text { Men } \\
N=317\end{array}$ & $\begin{array}{c}\text { chi-square test } \\
p\end{array}$ \\
\hline "lifestyle": & & & & \\
Not good & $2(0.3 \%)$ & $0(0.0 \%)$ & $2(0.6 \%)$ & 0.001 \\
Good & $201(32.0 \%)$ & $80(25.6 \%)$ & $121(38.2 \%)$ & \\
Very good & $426(67.7 \%)$ & $232(74.4 \%)$ & $194(61.2 \%)$ & \\
\hline
\end{tabular}

Source: own research.

A significant statistical difference was observed between female students and male students due to the level of the "lifestyle" meter. The number of women with a good lifestyle was significantly lower than that of men $(25.6 \%$ vs. $38.2 \%, p=0.001)$. The proportion of female students with a very good quality of life was higher than that of male students $(74.4 \%$ vs. $61.2 \%, p<0.001)$. Women's lifestyle was rated significantly higher than men $(p<0.001)$ (Table 5).

However, no differences between lifestyle and place of residence were observed $(p=0.681, p>0.05)$ and the type of university $(p=0.121, p>0.05)$. 


\section{THE LEVEL OF PHYSICAL ACTIVITY OF ACADEMIC YOUTH}

A good level of SPM "physical activity currently" was achieved by $74.2 \%$ of students. At all universities, the percentage of students who achieved this level was different and was respectively: at UWr $76.2 \%$, at PWr $72.8 \%$ at UM $73.8 \%$. Not very good level of SPM "physical activity currently" received $19.9 \%$ of students. In this group were the students of PWr 24.4\% and UM 15.0\%. Only 5.9\% of people achieved the very good level of SPM "physical activity currently," including students from UM (11.2\%) (Table 6).

\section{Table 6.}

Basic statistics (numbers and proportions) of students differing in the SPM level of "physical activity currently" and the type of university.

\begin{tabular}{lccrrc}
\hline Level of the meter: & $\begin{array}{c}\text { Overall } \\
N=629\end{array}$ & $\begin{array}{c}\text { UWr } \\
N=206\end{array}$ & $\begin{array}{c}\text { PWr } \\
N=217\end{array}$ & $\begin{array}{c}\text { UM } \\
N=206\end{array}$ & $\begin{array}{c}\text { Chi-square } \\
\text { test } \\
\boldsymbol{p}\end{array}$ \\
\hline $\begin{array}{c}\text { "physical activity } \\
\quad \text { currently": }\end{array}$ & & & & & 0.001 \\
$\begin{array}{l}\text { Not very good } \\
\text { Good }\end{array}$ & $125(19.9 \%)$ & $41(19.9 \%)$ & $53(24.4 \%)$ & $31(15.0 \%)$ & \\
Very good & $467(74.2 \%)$ & $157(76.2 \%)$ & $158(72.8 \%)$ & $152(73.8 \%)$ & \\
\hline
\end{tabular}

Source: own research.

In the studied group of students, there is a statistically significant difference between the levels of SPM "physical activity currently" $(p=0.001)$. The proportion of UWr students who achieved very good SPM "physical activity currently" was significantly lower than that of UM students ( $3.9 \%$ vs. $11.2 \%, p=0.005)$. The percentage of PWr students with the not-very-good SPM level "physical activity currently" was higher than that of UM students ( $24.4 \%$ vs. $15.0 \%, p=0.016)$, and the percentage of PWr students with physical activity at the very good level was lower than that of students UM (2.8\% vs. $11.2 \%, \mathrm{p}=0.001)($ Table 7$)$.

Table 7.

The result of multiple comparisons of SPM level "physical activity currently."

\begin{tabular}{lccc}
\hline $\begin{array}{c}\text { Level of the meter "physical } \\
\text { activity currently" }\end{array}$ & UWr vs. PWr & UWr vs. UM & PWr vs. UM \\
\hline Not very good & $p=0.266$ & $p=0.191$ & $p=0.016$ \\
Good & $p=0.423$ & $p=0.574$ & $p=0.816$ \\
Very good & $p=0.529$ & $p=0.005$ & $p=0.001$ \\
\hline
\end{tabular}

Source: own research.

The synthetic partial measure "physical activity currently" of UM students in Wrocław is at a higher level than students of other universities $(p<0.001)$. The difference between the UWr and PWr is not statistically significant ( $p>$ 0.05) (Table 8). 
Table 8.

SPM "physical activity currently." The result of multiple comparisons with the post-hoc test (significance levels of p-differences).

\begin{tabular}{|c|c|c|c|}
\hline University & $\begin{aligned} & \text { 1. UWr } \\
\bar{x}= & 0.676\end{aligned}$ & $\begin{array}{l}\text { 2. PWr } \\
\bar{x}=0.674\end{array}$ & $\begin{array}{l}\text { 3. UM } \\
\bar{x}=0.705\end{array}$ \\
\hline 1. University of Wrocław & & 0.837 & 0.001 \\
\hline $\begin{array}{l}\text { 2. Wrocław University of Science } \\
\text { and Technology }\end{array}$ & 0.837 & & $<0.001$ \\
\hline 3. Wrocław Medical University & 0.001 & $<0.001$ & \\
\hline
\end{tabular}

Among the students of all universities, the highest percentage of people (74.2\%) achieved a good level of SPM "physical activity currently," including 242 women (77.6\%) and 225 men (71.0\%). 125 people (19.9\%) achieved unbelievable levels, including 61 men $(19.2 \%)$ and 64 women $(20.5 \%)$. The smallest percentage of male students $(5.9 \%)$ received a very good level of the meter and only 6 female students $(1.9 \%)$ achieved a very good level of SPM "physical activity currently" (Table 9).

Table 9.

Basic statistics (numbers and proportions) of students differing in the level of SPM "physical activity currently" due to gender.

\begin{tabular}{lcccc}
\hline Level of the meter: & $\begin{array}{c}\text { Overall } \\
N=\mathbf{6 2 9}\end{array}$ & $\begin{array}{c}\text { Women } \\
N=312\end{array}$ & $\begin{array}{c}\text { Men } \\
N=317\end{array}$ & $\begin{array}{c}\text { Chi-square } \\
\text { test } \\
p\end{array}$ \\
\hline $\begin{array}{c}\text { "physical activity } \\
\quad \text { currently": }\end{array}$ & & & & \\
Not very good & $125(19.9 \%)$ & $64(20.5 \%)$ & $61(19.2 \%)$ & \\
Good & $467(74.2 \%)$ & $242(77.6 \%)$ & $225(71.0 \%)$ & \\
Very good & $37(5.9 \%)$ & $6(1.9 \%)$ & $31(9.8 \%)$ & $<0.001$ \\
\hline
\end{tabular}

Source: own research.

Multiple comparisons of the level of physical activity showed that the proportion of female students with the "physical activity currently" at the very good level was lower than that of male students (1.9\% vs. 9.8\%, p <0.001). SPM "physical activity currently" of male students is at a higher level than female students (Table 9).

Among all students, 74.2\% achieved a good level of SPM "physical activity currently" comparatively living in rural areas (75.5\%) and in the city $(73.8 \%)$. The insufficient level of the meter was obtained by $19.9 \%$ of students, including more often in the city $(21.3 \%)$ compared to the rural population $(15.5 \%)$. Only $5.9 \%$ of students were characterised by a very good level of SPM "physical activity currently". There was no statistically significant relationship between the place of residence and the SPM level of "physical activity currently" ( $p>0.05)$ (Table 10). 
Table 10.

Basic statistics (numbers and proportions) of students differing in the level of SPM "physical activity currently" and place of residence.

\begin{tabular}{lcccc}
\hline Level of the meter: & $\begin{array}{c}\text { Overall } \\
N=\mathbf{6 2 9}\end{array}$ & $\begin{array}{c}\text { Cottage } \\
\boldsymbol{N}=\mathbf{1 5 5}\end{array}$ & $\begin{array}{c}\text { City } \\
\boldsymbol{N}=\mathbf{3 1 7}\end{array}$ & $\begin{array}{c}\text { Chi-square } \\
\text { test } \\
\boldsymbol{p}\end{array}$ \\
\hline $\begin{array}{c}\text { "physical activity } \\
\quad \text { currently": }\end{array}$ & & & & 0.064 \\
Not very good & $125(19.9 \%)$ & $24(15.5 \%)$ & $101(21.3 \%)$ & \\
Good & $467(74.2 \%)$ & $117(75.5 \%)$ & $350(73.8 \%)$ & \\
Very good & $37(5.9 \%)$ & $14(9.0 \%)$ & $23(4.9 \%)$ & \\
\hline
\end{tabular}

Source: own research.

\section{PHYSICAL ACTIVITY VS HEALTH AND LIFESTYLE}

Between SPM "physical activity currently" and SPM "lifestyle" there is a statistically significant $(\mathrm{p}<0.05)$ positive correlation (Table 11). Although the correlation is statistically significant, it is very small, which indicates a possible lack of interdependence between the examined variables.

Table 11.

Rank correlation coefficient (Spearman) rS for individual meters.

\begin{tabular}{cccc}
\hline SPM & Body weight (kg) & "health status" & "lifestyle" \\
\hline "physical activity & $r_{S}=0.073$ & $r_{S}=0.020$ & $r_{S}=0.099$ \\
currently" & sn & sn & p $<0.05$ \\
\hline
\end{tabular}

Note: sn - statistically negligible

Source: own research.

A weak positive correlation of SPM "lifestyle" with SPM "health status" of all subjects was observed. However, these correlations are also too small.

Table 12.

Pearson correlation coefficients SPM “lifestyle" students from SPM "health status."

\begin{tabular}{ccc}
\hline & University & \\
\hline UWr & PWr & UM \\
$\mathrm{n}=206$ & $\mathrm{n}=217$ & $\mathrm{n}=206$ \\
\hline$r=+\mathbf{0 . 1 4 5}$ & $r=+0.088$ & $r=+\mathbf{0 . 2 0 2}$ \\
$p=\mathbf{0 . 0 3 7}$ & $p=0.195$ & $p=0.004$ \\
\hline
\end{tabular}

Source: own research. 


\section{HEALTH POTENTIAL}

The health potential (measured by STM) of $2 / 3$ of the surveyed students $(68.4 \%)$ was at a very good level. At the UWr, it concerned 148 people $(71.8 \%)$, PWr 144 people (66.4\%) and at UM 138 people (67\%). A good level of STM was assigned to one in three students $(31.6 \%)$, including PWr 73 people $(33.6 \%)$, similarly to UM 68 people (33.0\%) and 58 people $(28.25 \%)$ at the UWr.

Table 13.

Basic statistics (numbers and proportions) of students differing in the level of STM

\begin{tabular}{lccccc}
\hline $\begin{array}{c}\text { Level of the } \\
\text { meter: }\end{array}$ & $\begin{array}{c}\text { Overall } \\
N=629\end{array}$ & $\begin{array}{c}\text { UWr } \\
N=206\end{array}$ & $\begin{array}{c}\text { PWr } \\
N=217\end{array}$ & $\begin{array}{c}\text { UM } \\
N=206\end{array}$ & $\begin{array}{c}\text { Chi-square } \\
\text { test } \\
p\end{array}$ \\
\hline \multicolumn{1}{c}{ STM } & & & & & 0.420 \\
$\begin{array}{l}\text { Good } \\
\text { Very good }\end{array}$ & $439(31.6 \%)$ & $58(28.2 \%)$ & $73(33.6 \%)$ & $68(33.0 \%)$ & \\
\hline
\end{tabular}

Source: own research.

Among the students of all universities, the largest number of students from UWr (148 people) obtained a very good level of the synthetic comprehensive gauge (STM). However, a good level of STM was assigned to the most students from PWr (73 people). No student had a level: not very good, bad or very bad STM.

It should be noticed that the synthetic overall measure (health potential) was high regardless of place of residence $(p=0.546, p>0.05)$, gender $(p=0.135$, $p>0.05)$ and the type of university $(p=0.420, p>0.05)$.

\section{DISCUSSION}

Taking up pro-health behaviour plays an important role in the health promotion. The period of study is the last stage of education, during which health education focused on developing, maintaining and monitoring physical activity to ensure the quality of life at the highest level is conducted on a large scale. Much health behaviour is interrelated. Involvement in one health behaviour can affect engagement in other behaviour (Nudelman, Kalish, \& Shiloh, 2019).

The first examined aspect at work was health. Scientific research proves that the increase in life expectancy is noticeable. At the same time, aging processes begin much earlier and progress much faster than in previous generations, while the symptoms of civilisation diseases appear at an increasingly young age (Sochocka \& Wojtyłko, 2013). It is expected that the activities undertaken during the studies, aiming at dissemination of pro-health lifestyle in free time will result in an active, positive attitude of graduates of various universities towards the problems of health prevention and creating conditions for the development of physical culture (Kochanowicz, \& Hansdorfer-Korzon, 2013). 
Good health can be the result of the age of the examined people and the place of research (universities). They were young people, whose health allowed for educational activity.

In addition, research shows that education has a positive influence on health. Along with the increase in education, greater health awareness and increased preferences for a healthy lifestyle are observed (Becchetti, Conzo, \& Pisani, 2018).

According to CBOS (Centre for Public Opinion Research) surveys from 2016, Poles are satisfied with their health condition. Over half of the respondents (55\%) assess their health as at least good at least every eighth Pole (13\%) is satisfied with their health condition. Dissatisfaction is expressed by $9 \%$ of respondents, and over one third (36\%) assess their health as such: neither good nor bad. Still, for several years, the tendency of satisfaction with one's own health has persisted among Poles. Complaining about your health increases, which is quite obvious, with the age of the respondents, while in the group of people between 18-34. the majority of people declare satisfaction with their state of health (80-85\%) (CBOS BS / 138/2016).

Similar results in the group of students from Wroclaw, where health is the highest rated aspect of all considered in our work, were received. Almost all students $(99,8 \%)$ assess their health condition as very good. There was no statistically significant relationship between SPM "health" and gender and place of residence.

Katarzyna Prusik and co-authors came to similar results, showing that 90.9\% of students of the Academy of Physical Education and Sport in Gdańsk recognize their health condition as very good and good (Prusik, Zaporozhanov, Gorner, \& Prusik, 2009).

However, in Alicja Kostencka's research, it reads that the state of health of academic youth from the Kazimierz Wielki University in Bydgoszcz is disturbing, especially in the case of chronic diseases. Over 30\% report having at least one of these types of diseases, most often with back pain (almost 16\% of women). One or two diseases in the last year were reported by almost $30 \%$ of the respondents, and more than two diseases a year affected $12 \%$ of students (Kostencka, 2007).

The next discussed aspect of the work was lifestyle. Research shows that many health factors are related to a given type of lifestyle that also allows young people to plan future health strategies (Agostinis, Gómez, Nova, Hernandez, Labayen, Kafatos, \& Marcos, 2019). A pro-health lifestyle also influences academic performance, which in the case of adolescents is particularly important (Adelantado-Renau, Jiménez-Pavón, Beltran-Valls, \& Moliner-Urdiales, 2019).

One of the most important lifestyle factors is the relationship between physical activity and health. Lifestyle influences not only our health condition, but also the quality of the whole human life. In her multi-centre study of students throughout Poland, Kowalska has proven that students declare a very active and healthy lifestyle (Kowalska, 2005).

Similarly, our results indicate that $67.7 \%$ of students achieved a very good level of SPM "lifestyle", and 32\% achieved a good SPM "lifestyle". Women's 
lifestyles were rated significantly higher than men. There was no statistically significant relationship between the place of residence and the SPM "lifestyle."

According to the results of Rafał Poręba and co-authors, the lifestyle and eating habits of Wroclaw's students do not differ significantly in the aspects compared to the average adult's lifestyle. The studied group of students is characterised by similar dissemination of cardiovascular disease risk factors and non-compliance with the diet, too low consumption of cereal, dairy, fruit and vegetables (Poręba, Gać, Zawadzki, Poręba, Derkacz, Pawlas, Pilecki, \& Andrzejak, 2008)

A. Kostencka proved that only $6 \%$ of the surveyed students present a highly pro-health lifestyle, and as much as $43 \%$ exhibit a low degree while $11 \%$ of students a very low pro-health lifestyle. According to the author, there are differences in pro-health behaviour between men and women. It turns out that in the case of men, pro-health behaviour decreases over subsequent years of studies (Kostnecka, 2007).

The last of the described aspects at work is physical activity. Studies show that even the minimum recommended physical activity brings long-term health benefits (Lechner, Sari, 2015). Physical activity affects various aspects related to health, reduces obesity and overweight and reduces the cardiovascular risk among adolescents (Hayes, Eisenmann, Laurson, DuBose, Reeves, Carlson, Pfeiffer, 2018), reduces the risk of lung cancer (Patel, Carter, Stevens, Gaudet, Campbell, Gapstur, Gapstur, 2017). As is evident from the meta-analysis - which was carried out by Anne-Marie Bagnall et al. (2019) - defeating individual problems, such as obesity, which can be caused by lack of adequate physical activity, requires coordinated, interdisciplinary activities carried out at all levels of health management throughout the life cycle of an individual.

In recent decades, in Poland and around the world, anti-health behaviour has been growing among students, among which one should mention a reduction in physical activity (Marcysiak, Zagroba, \& Ostrowska, 2010). Academic youth from all social groups are particularly vulnerable to many phenomena that adversely affect health.

Studies carried out by CBOS (Centre for Public Opinion Research) show that physical activity of respondents depends to a large extent on their age, education and financial situation. The younger the age, higher level of education, better assessment of the material situation, the higher the percentage of respondents practicing sport. 95\% of the respondents aged 18-24 declare practicing sports during the last year. There is also a noticeable correlation between taking up physical activity and the place of residence and gender. Doing sport is more common among urban residents than the ones living in rural areas (72\% vs. 56\%) and slightly more often among men than women (69\% vs. 63\%) (CBOS, BS / 129/2013).

In our research, $74.2 \%$ of students achieved a good level of SPM "physical activity currently," 19.9\% not very good level, and only $5.9 \%$ of students achieved a very good level of SPM "physical activity currently." SPM "physical activity currently" of students is at a higher level than that of female students. There was no significant statistical relationship between the place of residence and the SPM level of "physical activity currently." 
Ewa Smoleń and Lucyna Gazdowicz (2012) described in their research that more than half of Sanok university students assessed their physical activity as of a good level. Similarly, at Lublin universities, almost half $(45 \%)$ of the students rated their physical activity at a good level, and $44 \%$ at a sufficient level. The highest level of physical activity, as in our research, was achieved by the least students: $7 \%$ at the University of Lublin and 8.8\% at Sanok (Smolen \& Gazdowicz, 2012). At the university in Sanok, men (61.3\%) more often assessed the level of their physical activity as good than women (49.4\%). E. Smolen also showed a significant dependence of the regularity of physical activity undertaken on the sex of the subjects. Men (71\%) more often than women (31\%) trained more regularly, just like in our research.

Different results in this aspect were obtained by Barbara Duda among students of AWFiS in Gdańsk, where $60.3 \%$ of women decided more often than men $(40.3 \%)$ that their physical activity is of good level, and $56.2 \%$ of male students as well as $32.7 \%$ of female students rated his physical activity at a very good level, which is significantly different from the results obtained in our own research as well as at the university in Sanok and the university in Lublin (Duda, 2005).

In his work, Anna Gawel showed that only every fifth student $(21.6 \%)$ of Kraków's universities exercises regularly while others take physical exercise occasionally $(52 \%)$, very rarely exercise $23.2 \%$, no exercises are performed by $3.3 \%$ of students from Kraków (Gaweł, 2007).

For the majority of young people, the university is the last stage before embarking on adult life. It is also the last stage before starting to work. Study time should consolidate positive habits of a healthy lifestyle based on a properly balanced diet, maintaining a healthy body mass, avoiding such stimulants as: cigarettes, alcohol, drugs, respecting the right amount of sleep. During this period, the cultural preferences and cultural needs of a young man crystallize. One of many activities serving to maintain health is the right amount of physical activity and a healthy lifestyle. Analysis of physical activity, health status and lifestyle of young people is important for the assessment of the health situation in a society (Rasińska, 2010).

\section{CONCLUSIONS}

The level of health potential of the surveyed students designated by the synthetic comprehensive measure (STM) has been assessed well or very well. The health of students is at a very good level regardless of gender, origin and type of university.

The lifestyle of Wrocław's university students is at similar levels. It was rated significantly higher among women than among men. Students who maintain a healthy lifestyle more often perform physical activity and have better health.

Physical activity of students from the Medical University of Wrocław is at a higher level than students of the Wrocław University of Technology and the University of Wrocław. Men perform physical activity more often than women. The level of body mass index (BMI) and place of residence (city, village) did not affect the student's physical activity. 


\section{REFERENCES}

1. Adelantado-Renau, M., Jiménez-Pavón, D., Beltran-Valls, M. R., \& Moliner-Urdiales, D. (2019). Independent and combined influence of healthy lifestyle factors on academic performance in adolescents: DADOS Study. Pediatric Research, 85(4), 456-462. https://doi.org/10.1038/ s41390-019-0285-z

2. Agostinis-Sobrinho, C., Gómez-Martínez, S., Nova, E., Hernandez, A., Labayen, I., Kafatos, A., Gottand, F., Molnár, D., Ferrari, M., Moreno, L. A., González-Gross, M., Michels, N., Ruperez, A., Ruiz, J. R., \& Marcos, A. (2019). Lifestyle patterns and endocrine, metabolic, and immunological biomarkers in European adolescents: The HELENA study. Pediatric Diabetes, 20(1), 23-31. https://doi.org/10.1111/pedi.12802

3. Bagnall, A.M., Radley, D., Jones, R., Gately, P., Nobles, J., Van Dijk, M., Blackshaw, J., Montel, S., \& Sahota, P. (2019). Whole systems approaches to obesity and other complex public health challenges: a systematic review. BMC Public Health, 19(1), N.PAG. https://doi.org/10.1186/ s12889-018-6274-z

4. Bąk- Romaniszyn L., (ed.) (2013). Choroby spoteczne i cywilizacyjne - wybrane zagadnienia [Social and civilization diseases - selected issues]. Łódź: Medical Uniwersity in Łódź.

5. Becchetti, L., Conzo, P., \& Pisani, F. (2018). Education and health in Europe, Applied Economics, 50(12), 1362-1377. Retrieved from: https:/ / doi.org/10.1080/00036846.2017.1361013

6. Biernat, E. (2011). Aktywność fizyczna mieszkańców Warszawy na przyktadzie wybranych grup zawodowych [Physical activity of Warsaw residents on the example of selected groups based on profession]. Warsaw: SGH.

7. Chen., X., de Vries, S., Assmuth, T., Dick, J.,Hermans, T., Hertel, O., Jensen, A., Jones, L., Kabisch, S., Lanki, T., Lehmann, I., Maskell, L., Norton, L., \& Reis, S. (2019). Research challenges for cultural ecosystem services and public health in (peri-)urban environments. Science of the Total Environment, 651, 2118-2129. https:// doi.org/10.1016/j.scitotenv.2018.09.030

8. Communication from CBOS [Centre for Public Opinion Research], Aktywność fizyczna Polaków [Physical activity of Poles], BS/129/2013, 1-2.

9. Communication from CBOS [Centre for Public Opinion Research], Zdrowie i zachowania prozdrowotne Polaków [Health and pro-health behaviour of Poles], (pp. 3-4). Retrieved from: http://www.cbos.pl/SPISKOM.POL/2016/K_138_16.PDF

10. Drygas, W., Skiba, A., Bielecki, W., \& Puska, P., (2001). Ocena aktywności fizycznej mieszkańców sześciu krajów europejskich. Projekt Bridging East-West Health Gap. [Assessment of physical activity of residents of six European countries. Bridging East-West Health Gap Project]. Medicina Sportiva, 5 (2), 119.

11. Duda, B. (2005). Aktywność fizyczna studentów Akademii Wychowania Fizycznego i Sportu w Gdańsku przyktadem zdrowego stylu życia [Physical activity of students of the Academy of Physical Education and Sport in Gdańsk as an example of a healthy lifestyle]. Annalles Universitatis Mariae Curie-Skłodowska, vol. LX. Suppl. XVI, 84,Sectio D, 387-390.

12. Gaweł, A. (2007). Sposoby spędzania czasu wolnego przez studentów pedagogiki w kontekście ich świadomości zdrowotnej [Ways of spending free time by students of pedagogy in the context of their health awareness], In: Skulicz (ed.) Studenci we wspólnocie akademickiej [Students in the academic community], (pp.191-198). Kraków: Wydawnictwo Uniwersytetu Jagiellońskiego.

13. Grabowska, B. (2017). Unpublished Doctoral Dissertation. Aktywność fizyczna, wybrane elementy stylu życia i wskaźnik masy ciała wrocławskich studentów [Physical activity, selected lifestyle elements and body mass index of Wroclaw students]. Wrocław: Medical University Piastów Śląskich.

14. Hayes Betz, H., Eisenmann, J. C., Laurson, K. R., DuBose, K. D., Reeves, M. J., Carlson, J. J., \& Pfeiffer, K. A. (2018). Physical Activity, BMI, and Blood Pressure in US Youth: NHANES 20032006. Pediatric Exercise Science, 30(3), 418-425. https://doi.org/10.1123/pes.2017-0127

15. Pomerlau, J., Pereson, L. L., Ostbye, T., Speechley, M., \& Speechley, K.N. (1997). Health behaviours and socio-economic status in Ontario, Canada, European Journal of Epidemiology, 13 (6), 613-622.

16. Kochanowicz, B., \& Hansdorfer-Korzon, R. (2013). Postawy studentów kierunku fizjoterapii wobec aktywności fizycznej. [Attitudes of physiotherapy students towards physical activity], Annales Academiae Medicae Gedanensis,43, 19-28. 
17. Kostencka, A., Drabik J. (2007). Aktywność fizyczna a inne zachowania prozdrowotne studentów [Physical activity versus other pro-health behavior of students]. Annales Universitatis Mariae Curie - Skłodowska. Vol. LXII, suppl. XVIII, 3, Sectio D. s. 403-406.

18. Kowalska, J. E. (2005). Styl życia i aktywność ruchowa studentów uczelni wychowania fizycznego w Polsce w aspekcie edukacji zdrowotnej [Lifestyle and physical activity of students of physical education in Poland in the aspect of health education], Kultura Fizyczna , 7(8), 11-15.

19. Lechner, M., \& Sari, N. (2015). Labor market effects of sports and exercise: Evidence from Canadian panel data. Labour Economics, 35, 1-15. https:/ / doi.org/10.1016/j.labeco.2015.04.001

20. Marcysiak, M., Zagroba M., Ostrowska B, \& Wiśniewska E. (2010). Aktywność fizyczna, a zachowania żywieniowe dzieci $i$ młodzieży powiatu ciechanowskiego [Physical activity, and nutritional behavior of children and youth of the Ciechanow district], Problemy Pielegniarstwa, 18 (2), 176-183.

21. Ministry of Sport and Tourism (2019). Raport końcowy Ocena realizacji zadań własnych jednostek samorządu terytorialnego (JST) w zakresie zaspokajania zbiorowych potrzeb wspólnoty odnoszacych się do spraw kultury fizycznej i turystyki, w tym terenów rekreacyjnych i urządzeń sportowych [Final report Assessment of the implementation of own tasks of local government units in the scope of satisfying the collective needs of the community relating to physical culture and tourism, including recreational areas and sports equipment] (pp. 57, 69). Retrieved from: https:// www.msit.gov.pl/pl/sport/badania-i-analizy/aktywnosc-fizyczna-spol/575,Aktywnoscfizyczna-spoleczenstwa.html

22. Nudelman, G., Kalish, Y., \& Shiloh, S. (2019). The centrality of health behaviours: A network analytic approach. British Journal of Health Psychology, 24(1), 215-236. https:/ / doi.org/10.1111/ bjhp.12350

23. Patel, A.V., Carter, B.D., Stevens, V.L., Gaudet, M.M., Campbell, P.T., \& Gapstur, S.M. (2017). The relationship between physical activity, obesity, and lung cancer risk by smoking status in a large prospective cohort of US adults. Cancer Causes $\mathcal{E}$ Control, 28(12), 1357-1368. https:// doi.org/10.1007/s10552-017-0949-0

24. Poręba, R., Gać P., Zawadzki, M., Poręba, M., Derkacz, A., Pawlas, K., Pilecki W., \& Andrzejak R. (2008). Styl życia i czynniki ryzyka chorób układu krążenia wśród studentów uczelni Wrocławia [Lifestyle and cardiovascular risk factors among students of the Wrocław University], Polskie Archiwum Medycyny Wewnętrznej, 118(3), 1-8.

25. Prusik K., Zaporozhanov V., Görner K., \& Prusik, K. (2009) [Stan aktywności fizycznej w stylu życia studentów Akademii Wychowania Fizycznego i Sportu w Gdańsku] State of physical activity in the lifestyle of students of the physical education and sports academy in Gdansk. Проблеми фізичного виховання і спорту, 12, 229 - 233.

26. Rasińska, R. (2010). Analiza wybranych wyznaczników kształtowania postaw zdrowotnych młodzieży akademickiej [Analysis of selected determinants of shaping the health attitudes of academic youth] Doctoral dissertation. Poznań: UM, Wydział Nauk o Zdrowiu.

27. Smoleń E., Gazdowicz L., (2012). Ocena aktywności fizycznej młodzieży akademickiej [Assessment of physical activity of academic youth], Pielegniarstwo XXI wieku, nr 4(41), 99-101.

28. Sochocka, L., Wojtyłko, A., (2013). Aktywność fizyczna studentów studiów stacjonarnych kierunków medycznych $i$ niemedycznych [Physical activity of full-time students of medical and non-medical fields], Medycyna Środowiskowa, 16, no 2, 53-58.

29. Varo, J. J., Martínez-González, M. A., De Irala-Estévez, J., Kearney, J., Gibney, M., \& Martínez, J. A. (2003). Distribution and determinants of sedentary lifestyles in the European Union. International Journal Of Epidemiology, 32(1), 138-146. Retrieved from http:/ / search.ebscohost.com/ login.aspx?direct=true\&db=cmedm\&AN=12690026\&lang=pl\&site=ehost-live 